Article

\title{
Enzymatic Epoxidation of Long-Chain Terminal Alkenes by Fungal Peroxygenases
}

\author{
Esteban D. Babot ${ }^{1}{ }^{(D}$, Carmen Aranda $^{2}$, Jan Kiebist ${ }^{3}$, Katrin Scheibner ${ }^{3}$, René Ullrich ${ }^{4}$, Martin Hofrichter ${ }^{4}$ (D) \\ Angel T. Martínez ${ }^{5}$ (D) and Ana Gutiérrez ${ }^{1, *}$
}

check for updates

Citation: Babot, E.D.; Aranda, C.; Kiebist, J.; Scheibner, K.; Ullrich, R.; Hofrichter, M.; Martínez, A.T.; Gutiérrez, A. Enzymatic Epoxidation of Long-Chain Terminal Alkenes by Fungal Peroxygenases. Antioxidants 2022, 11, 522. https://doi.org/ $10.3390 /$ antiox 11030522

Academic Editor: Stanley Omaye

Received: 10 February 2022

Accepted: 7 March 2022

Published: 8 March 2022

Publisher's Note: MDPI stays neutral with regard to jurisdictional claims in published maps and institutional affiliations.

Copyright: (C) 2022 by the authors. Licensee MDPI, Basel, Switzerland. This article is an open access article distributed under the terms and conditions of the Creative Commons Attribution (CC BY) license (https:// creativecommons.org/licenses/by/ $4.0 /)$.
1 Instituto de Recursos Naturales y Agrobiología de Sevilla, Consejo Superior de Investigaciones Científicas (CSIC), 41012 Seville, Spain; edbabot@irnase.csic.es

2 Johnson Matthey, Cambridge Science Park U260, Cambridge CB4 0FP, UK; carmen.aranda@matthey.com

3 Institute of Biotechnology, Brandenburg University of Technology Cottbus-Senftenberg, 01968 Senftenberg, Germany; jan.kiebist@b-tu.de (J.K.); katrin.scheibner@b-tu.de (K.S.)

4 Unit of Bio- and Environmental Sciences, International Institute Zittau, TU Dresden, 02763 Zittau, Germany; ullrich@tu-dresden.de (R.U.); martin.hofrichter@tu-dresden.de (M.H.)

5 Centro de Investigaciones Biológicas "Margarita Salas", Consejo Superior de Investigaciones Científicas (CSIC), 28040 Madrid, Spain; atmartinez@cib.csic.es

* Correspondence: anagu@irnase.csic.es; Tel.: +34-954624711

\begin{abstract}
Terminal alkenes are among the most attractive starting materials for the synthesis of epoxides, which are essential and versatile intermediate building blocks for the pharmaceutical, flavoring, and polymer industries. Previous research on alkene epoxidation has focused on the use of several oxidizing agents and/or different enzymes, including cytochrome P450 monooxygenases, as well as microbial whole-cell catalysts that have several drawbacks. Alternatively, we explored the ability of unspecific peroxygenases (UPOs) to selectively epoxidize terminal alkenes. UPOs are attractive biocatalysts because they are robust extracellular enzymes and only require $\mathrm{H}_{2} \mathrm{O}_{2}$ as cosubstrate. Here, we show how several UPOs, such as those from Cyclocybe (Agrocybe) aegerita (AaeUPO), Marasmius rotula (MroUPO), Coprinopsis cinerea (rCciUPO), Humicola insolens (rHinUPO), and Daldinia caldariorum (rDcaUPO), are able to catalyze the epoxidation of long-chain terminal alkenes (from $C_{12: 1}$ to $C_{20: 1}$ ) after an initial optimization of several reaction parameters (cosolvent, cosubstrate, and $\mathrm{pH}$ ). In addition to terminal epoxides, alkenols and other hydroxylated derivatives of the alkenes were formed. Although all UPOs were able to convert and epoxidize the alkenes, notable differences were observed between them, with $\mathrm{rCciUPO}$ being responsible for the highest substrate turnover and MroUPO being the most selective with respect to terminal epoxidation. The potential of peroxygenases for epoxidizing long-chain terminal alkenes represents an interesting and green alternative to the existing synthesis technologies.
\end{abstract}

Keywords: peroxygenases; oxyfunctionalization; epoxidation; terminal alkenes; epoxides

\section{Introduction}

The importance of epoxides in the chemical industry is based on their high reactivity. There are innumerable reactions that epoxides can undergo with a variety of chemical compounds, which makes them valuable intermediates in organic synthesis. The epoxidation of alkenes provides oxirane compounds (epoxides) that are essential raw materials in the production of fine chemicals (such as surfactants, epoxy resins, perfumes, plasticizers, pharmaceuticals, agrochemicals, polymers, cosmetics, or paints) and are vital intermediate compounds in organic synthesis [1-3]. In this regard, terminal alkenes are among the most attractive starting materials for chemical synthesis, as they are readily available in large-scale industrial processes and can be obtained on a smaller scale through a number of efficient, catalytic, and highly selective processes [4]. Furthermore, olefin epoxidation 
plays an important role in the valorization of biomass and byproducts of fossil oil refineries, yielding essential and versatile intermediate building blocks for the pharmaceutical, flavoring, and polymer industries [5].

For several years, investigation has focused on the use of ecologically friendly chemical oxidizers, such as $\mathrm{H}_{2} \mathrm{O}_{2}$, dioxygen $\left(\mathrm{O}_{2}\right)$, organic peracids $\left(\mathrm{R}-\mathrm{CO}_{3} \mathrm{H}\right)$, and alkyl hydroperoxides $\left(\mathrm{R}-\mathrm{O}_{2} \mathrm{H}\right)$, in alkenes oxidative reactions [6-13]. The advantage of $\mathrm{H}_{2} \mathrm{O}_{2}$ as an oxidizer is the formation of water $\left(\mathrm{H}_{2} \mathrm{O}\right)$ as the only byproduct, with the disadvantage of requiring the use of metallic catalysts [14-16]. Chemoenzymatic epoxidation using lipases and $\mathrm{H}_{2} \mathrm{O}_{2}$ has also been reported for alkene epoxidation [17]. Nevertheless, another alternative for the epoxidation of terminal alkenes is the use of enzymes as reported for nonheme monooxygenases, such as toluene, styrene and methane monooxygenases (MMO) [18-20], chloroperoxidase [21], and an engineered cytochrome P450 monooxygenase (P450) [22], which are often used as microbial whole-cell catalysts [23]. However, whole-cell biotransformation typically requires long incubation times and is limited by the toxicity of the reaction compounds for cells. Conversely, nonheme monooxygenases (except MMO) are specific enzymes and, in most cases, need cosubstrates as electron donors. P450s, in addition to requiring $\mathrm{NADH}$, often need an auxiliary flavin-enzyme module and have low stability. Moreover, although successful selective epoxidation of short-chain terminal alkenes has been reported with some of these enzymes, they are not able to epoxidize alkenes with chain lengths longer than eight carbons [18-20].

The main purpose of this study was to achieve the epoxidation of long-chain terminal alkenes with enzymes, particularly with fungal peroxygenases, also named unspecific peroxygenases (UPOs, EC.1.11.2.1), while taking advantage of the new enzymes discovered in the last few years [24]. UPOs represent a relatively new and appealing type of biocatalysts for organic synthesis, which, unlike P450s, are extracellular enzymes that are more stable and only require $\mathrm{H}_{2} \mathrm{O}_{2}$ for activation, with formation of $\mathrm{H}_{2} \mathrm{O}$ as a byproduct. UPOs have been shown to catalyze a variety of interesting oxygenation reactions, hydroxylation and epoxidation included [25,26], with more than 300 substrates already reported [27] including aromatic and heterocyclic substrates [28,29]; aliphatic compounds such as fatty acids, alkanes, fatty alcohols [25,30-38], steroids [39,40], and secosteroids [41,42]; and other flavor and fragrance compounds such as isophorone, ionones, and damascones $[43,44]$. The first UPO was described in the basidiomycetous fungus Cyclocybe (Agrocybe) aegerita [45] and, since then, a handful of other UPO enzymes have been isolated from other rather different wild-type species of Basidiomycota and Ascomycota, such as Coprinellus radians [46], Marasmius rotula [47], and Chaetomium globosum [40], which is indicative of their widespread occurrence in the fungal kingdom. In addition to these homologous wild-type (i.e., nonrecombinant) enzymes, there are other UPOs, e.g., from Coprinopsis cinerea and Humicola insolens, which are only known as recombinant proteins heterologously expressed by Novozymes A/S (Bagsvaerd, Denmark) in the mold Aspergillus oryzae [48]. Recently, a new UPO from the ascomycete Daldinia caldariorum has become available from Novozymes after gene expression in A. oryzae, being also expressible in Escherichia coli as a soluble and active enzyme [37]. The scarce studies on the reaction of these enzymes with terminal alkenes only include epoxidation of short alkenes (with low conversion rates) with A. aegerita UPO (AaeUPO) [33] or report unsuccessful epoxidation of a long terminal alkene $\left(\mathrm{C}_{14: 1}\right)$ with two different UPOs [32]. UPOs [33] and P450s [49] are inactivated during the reaction with terminal alkenes due to heme alkylation. In the present work, we aimed to expand these results, first studying the optimal conditions of the reactions to obtain epoxides from long-chain terminal alkenes $\left(C_{12: 1}\right.$ to $\left.C_{20: 1}\right)$ and then exploring the potential of different fungal peroxygenases in these reactions.

\section{Materials and Methods}

\subsection{Enzymes}

Aae UPO (isoform II of $46 \mathrm{kDa}$ ), the first fungal peroxygenase purified and described in 2004 [45], was prepared as a wild-type enzyme from liquid cultures of A. aegerita TM- 
A1 grown in a soybean-peptone medium. M. rotula peroxygenase (MroUPO; $32 \mathrm{kDa}$ as monomeric enzyme), another wild-type UPO, was isolated from cultures of the respective agaric fungus (DSM-25031) [47]. The UPO of C. globosum (CglUPO; $36 \mathrm{kDa}$ ) is the third wild-type peroxygenase prepared from the liquid cultures of this ascomycetous mold (DSM-62110) [40].

The recombinant enzymes from C. cinerea (rCciUPO; $44 \mathrm{kDa}), H$. insolens (rHinUPO), and $D$. caldariorum (rDcaUPO) were provided by Novozymes A/S. rCciUPO corresponds to the protein model 7249 from the sequenced C. cinerea genome available at JGI (http: / / genome.jgi.doe.gov / Copci1, accessed on 1 February 2022) used in several studies $[32,39,41]$. The sequences of $\mathrm{rHin} \mathrm{UPO}$ and $\mathrm{rDcaUPO}$ are included in Novozymes patents [48,50] and the former has already been used in oxyfunctionalization reactions [40,51]. These recombinant UPOs were expressed in A. oryzae [52]. All UPO proteins were purified by fast protein liquid chromatography (FPLC) using a combination of size-exclusion and ion-exchange chromatography on different anion and cation exchangers. Purification was confirmed by sodium dodecyl sulfate-polyacrylamide gel electrophoresis (SDS-PAGE) and UV-visible spectroscopy following the characteristic heme maximum of around $420 \mathrm{~nm}$ (Soret band of resting-state heme-thiolate proteins). Enzyme concentration was estimated according to the characteristic UV-visible band of the reduced UPO complex with carbon monoxide [53].

\subsection{Model Compounds}

Terminal alkenes, namely, 1-dodecene $\left(C_{12: 1}\right)$, 1-tridecene $\left(C_{13: 1}\right)$, 1-tetradecene $\left(C_{14: 1}\right)$, 1-pentadecene $\left(C_{15: 1}\right)$, 1-hexadecene $\left(C_{16: 1}\right)$, 1-heptadecene $\left(C_{17: 1}\right)$, 1-octadecene $\left(C_{18: 1}\right)$, 1-nonadecene $\left(C_{19: 1}\right)$, and 1-eicosene $\left(C_{20: 1}\right)$, were used as substrates of the above UPOs. Tetradecane-1,2-diol and 1,2-epoxytetradecane were used as standards in gas chromatographymass spectrometry (GC-MS) analyses. All reagents were purchased from Sigma-Aldrich (Saint Louis, MO, USA).

\subsection{Enzymatic Reactions}

Reactions (500 $\mu \mathrm{L}$ volume) with different model compounds $(1 \mathrm{mM})$ were performed at $30{ }^{\circ} \mathrm{C}$ in $50 \mathrm{mM}$ phosphate buffer at $\mathrm{pH} 5.5$ or 7.0. Different proportions of acetone or acetonitrile (0-60\%) as a cosolvent were tested. The enzyme concentration used was in the range of $2-3 \mu \mathrm{M}$. The cosubstrate $\mathrm{H}_{2} \mathrm{O}_{2}$ or tert-butyl hydroperoxide $(t \mathrm{BuOOH})$ was continuously added with a syringe pump at $5 \mu \mathrm{L} / \mathrm{h}$ (within $24 \mathrm{~h}$ ) or $60 \mu \mathrm{L} / \mathrm{h}$ (within $2 \mathrm{~h}$ ) to give a concentration in the reaction mixture of $0.5-3 \mathrm{mM}$. In control experiments, substrates were treated under the same conditions (including cosubstrate) but without an enzyme. Products from enzymatic reactions were extracted with ethyl acetate, which was evaporated under nitrogen $\left(\mathrm{N}_{2}\right)$ and derivatized with $\mathrm{N}, \mathrm{O}$-bis(trimethylsilyl)trifluoroacetamide (Supelco; Bellefonte, PA, USA) to be analyzed by GC-MS.

\subsection{GC-MS Analyses}

The analyses were performed with a Shimadzu (Kyoto, Japan) GC-MS QP 2010 Ultra system, using a fused-silica DB-5HT capillary column $(30 \mathrm{~m} \times 0.25 \mathrm{~mm}, 0.1 \mu \mathrm{m})$ from J\&W Scientific (Folsom, CA, USA). The oven was heated from $50{ }^{\circ} \mathrm{C}(1.5 \mathrm{~min})$ to $90{ }^{\circ} \mathrm{C}(2 \mathrm{~min})$ at $30{ }^{\circ} \mathrm{C} \mathrm{min}-1$, and then from $90{ }^{\circ} \mathrm{C}$ to $250{ }^{\circ} \mathrm{C}(15 \mathrm{~min})$ at $8{ }^{\circ} \mathrm{C} \mathrm{min}{ }^{-1}$. The injection was performed at $250{ }^{\circ} \mathrm{C}$ and the transfer line was kept at $300{ }^{\circ} \mathrm{C}$. Compounds were identified by comparison of their mass spectra and retention times with commercial standards and/or by comparison of their mass spectra with those present in the Wiley and NIST libraries.

\section{Results and Discussion}

The oxirane ring of epoxides has been termed the "lord of the chemical rings" due to reactivity and relevance in different organic syntheses of industrial importance [54]. In the present study, the selective epoxidation of long-chain terminal alkenes by several UPOs from the basidiomycetous fungi $A$. aegerita, $C$. cinerea, and $M$. rotula; and the ascomycetous 
species C. globosum, H. insolens, and D. caldariorum was investigated (using GC-MS analysis). The work started with an optimization of the reaction conditions (cosolvent- and peroxidetype included) using one particular alkene, 1-tetradecene $\left(\mathrm{C}_{14: 1}\right)$, and one UPO (CglUPO). Then, the study was extended to the above-mentioned UPOs and, finally, several alkenes $\left(C_{12: 1}\right.$ to $\left.C_{20: 1}\right)$ were tested as substrates of these UPOs under the optimized reaction conditions as described below.

\subsection{Optimization of Reaction Conditions (Cosolvent and Cosubstrate) for Conversion of 1-Tetradecene by CglUPO}

The reaction of 1-tetradecene $\left(\mathrm{C}_{14: 1}, 1 \mathrm{mM}\right)$ with $\mathrm{CglUPO}(2 \mu \mathrm{M})$ was studied (over $24 \mathrm{~h}$ reaction time) under various conditions. Due to the low solubility of alkenes in aqueous media, the cosolvent was the first parameter considered with the testing of different proportions of two solvents commonly used in UPO-catalyzed reactions, i.e., acetone and acetonitrile [31]. Substantial substrate conversion under the formation of different oxygenated derivatives was only observed when the proportion of the cosolvent was kept between $40 \%$ and $60 \%$ acetone (Figure $1 \mathrm{~A}$ ) or $40 \%$ acetonitrile (Figure 1B), with acetone attaining higher conversions, particularly at $60 \%$ concentration, in which the products concentration was almost twice as high $(212 \mu \mathrm{M}$ vs. $110 \mu \mathrm{M})$ than at $40 \%$. When higher acetone concentration (80\%) was used in the reaction, no substrate conversion was observed.
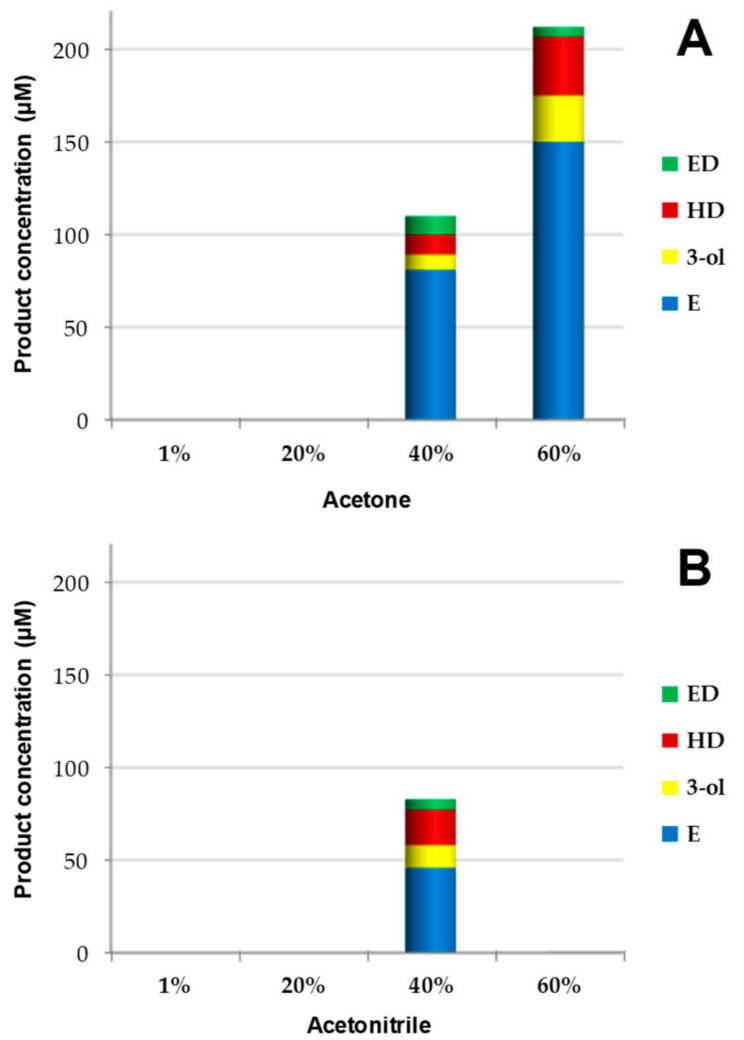

Figure 1. Reactions of $C g l \mathrm{UPO}(2 \mu \mathrm{M})$ with $0.5 \mathrm{mM}$ 1-tetradecene (over $24 \mathrm{~h}$ ) at several cosolvent concentrations: (A) acetone $\left(\mathrm{CH}_{3}-\mathrm{CO}-\mathrm{CH}_{3}\right) ;(\mathbf{B})$ acetonitrile $\left(\mathrm{CH}_{3}-\mathrm{CN}\right)$. Identified products: 1,2epoxytetradecane (E, blue), tetradecen-3-ol (3-ol, yellow), other alkene monohydroxylated derivatives (HD, red), and epoxide monohydroxylated derivatives (ED, green).

With both solvents, the main derivative of 1-tetradecene was the corresponding epoxide (E; 1,2-epoxytetradecane), although other hydroxylated derivatives (i) at the allylic position (3-ol, tetradecen-3-ol) and (ii) at other positions of the alkyl chain of tetradecene (HD) or of its epoxide (ED) were also produced (Scheme 1, Figure 1). The 1,2-epoxytetradecane 
(E) was identified by GC-MS analysis using its mass spectrum (Figure S1A) in comparison with those of the NIST library and an authentic standard. The positions of the hydroxyl group in the products (ED, 3-ol and HD) could be deduced from the mass spectra of the silylated derivatives, as illustrated in Figures S1B,C and S2.
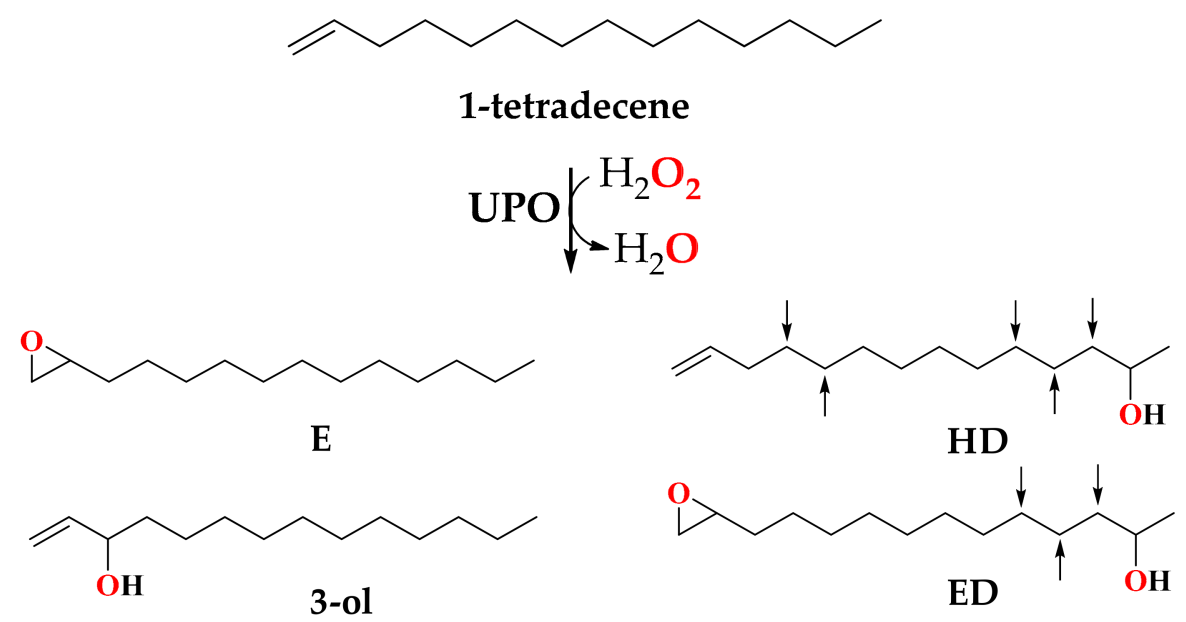

Scheme 1. Main products in UPO reactions with 1-tetradecene as substrate including: 1,2epoxytetradecane (E); monohydroxylated derivatives (HD); tetradecen-3-ol (3-ol); monohydroxylated epoxy-derivatives (ED). Arrows in the formulae of HD and ED indicate alternative positions of the hydroxyl group.

Since acetone is not oxidized by the enzyme, increases the solubility of alkenes in water mixtures, and hardly affects the activity of the enzyme [31], it was the solvent of choice for further studies.

The next reaction parameter studied was the cosubstrate type (peroxide acting as electron acceptor and source of oxygen) and its concentration, which is known to be one of the key factors determining UPO performance. On the one hand, high peroxide concentrations are required to achieve adequate yields; on the other hand, too-high concentrations can cause irreversible enzyme deactivation via UPO-compound III and subsequent hydroxyl radical formation [55]. Both hydrogen peroxide $\left(\mathrm{H}_{2} \mathrm{O}_{2}\right)$ and the milder (and more soluble in organic solvents) tert-butyl hydroperoxide $(t \mathrm{BuOOH})$ were tested at different concentrations (0.5-5 mM) in the presence of different amounts of CglUPO (Table 1).

Table 1. Total $(\mu \mathrm{M})$ and relative abundance (\%) of products (E, 3-ol, HD, and ED, see Scheme 1) from the reactions $(24 \mathrm{~h}, 60 \%$ acetone) of 1-tetradecene $(1 \mathrm{mM})$ with several doses of enzyme ( $\mathrm{CglUPO})$ and cosubstrates $\left(\mathrm{H}_{2} \mathrm{O}_{2}\right.$ or $\left.t \mathrm{BuOOH}\right)$.

\begin{tabular}{|c|c|c|c|c|c|c|c|}
\hline \multirow{2}{*}{$\begin{array}{c}\text { Enzyme } \\
(\mu \mathrm{M})\end{array}$} & \multirow{2}{*}{$\begin{array}{c}\text { Cosubstrate } \\
\text { (Type) }\end{array}$} & \multirow{2}{*}{$\begin{array}{l}\text { Cosubstrate } \\
(\mathrm{mM})\end{array}$} & \multirow{2}{*}{ Total $(\mu \mathrm{M})$} & \multicolumn{4}{|c|}{ Products $(\%)$} \\
\hline & & & & $\mathrm{E}$ & 3-ol & HD & ED \\
\hline 0.5 & $\mathrm{H}_{2} \mathrm{O}_{2}$ & 0.5 & 11 & 83 & 17 & 0 & 0 \\
\hline 0.5 & $\mathrm{H}_{2} \mathrm{O}_{2}$ & 1 & 51 & 64 & 13 & 24 & 0 \\
\hline 1 & $\mathrm{H}_{2} \mathrm{O}_{2}$ & 1 & 49 & 68 & 9 & 13 & 10 \\
\hline 1 & $\mathrm{H}_{2} \mathrm{O}_{2}$ & 5 & 46 & 63 & 10 & 23 & 4 \\
\hline 2 & $\mathrm{H}_{2} \mathrm{O}_{2}$ & 0.5 & 100 & 71 & 12 & 14 & 4 \\
\hline 2 & $\mathrm{H}_{2} \mathrm{O}_{2}$ & 1 & 195 & 72 & 12 & 14 & 2 \\
\hline 2 & $\mathrm{H}_{2} \mathrm{O}_{2}$ & 5 & 134 & 73 & 12 & 14 & 2 \\
\hline 2 & $t \mathrm{BuOOH}$ & 0.5 & 91 & 69 & 11 & 15 & 5 \\
\hline 2 & $t \mathrm{BuOOH}$ & 1 & 94 & 68 & 12 & 17 & 3 \\
\hline 2 & $t \mathrm{BuOOH}$ & 5 & 28 & 82 & 18 & 0 & 0 \\
\hline
\end{tabular}


For the same $C g l \mathrm{UPO}$ dose $(0.5,1$, or $2 \mu \mathrm{M})$, a higher product amount was always achieved with $1 \mathrm{mM}$ of $\mathrm{H}_{2} \mathrm{O}_{2}(51,49$, and $195 \mu \mathrm{M}$, respectively). When $t \mathrm{BuOOH}$ was used as the cosubstrate, the amount of product was lower in all cases compared to $\mathrm{H}_{2} \mathrm{O}_{2}(91$, 94 , and $28 \mu \mathrm{M}$ vs. 100, 195, and $134 \mu \mathrm{M}$, respectively). Regarding the reaction products (Scheme 1), 1,2-epoxytetradecane (E) was the main product in all cases, together with lower amounts of tetradecen-3-ol (3-ol), other monohydroxylated derivatives (HD) of tetradecene, and several monohydroxylated derivatives of 1,2-epoxytetradecane (ED). There was no clear relationship between the peroxide doses and the relative abundance of the above products (Table 1).

\subsection{Selective Epoxidation of 1-Tetradecene by Several UPOs}

The optimized reaction conditions found with $\mathrm{CglUPPO}(60 \%$ acetone and $1 \mathrm{mM}$ $\mathrm{H}_{2} \mathrm{O}_{2}$ ) were used to evaluate the selectivity of the different UPOs mentioned above with 1-tetradecene as the substrate. Two $\mathrm{pHs}$ (5.5 and 7.0) were tested based on the $\mathrm{pH}$ optima of previously reported UPOs $[28,40,47]$. The results revealed that all UPOs tested were able to convert 1-tetradecene, with rCciUPO achieving the highest levels, followed by rHinUPO and CglUPO (Table 2).

Table 2. Total $(\mu \mathrm{M})$ and relative abundance (\%) of products (E, 3-ol, HD, and ED, see Scheme 1) from the reactions ( $24 \mathrm{~h}, 60 \%$ acetone, $\left.1 \mathrm{mM} \mathrm{H}_{2} \mathrm{O}_{2}\right)$ of 1-tetradecene $(1 \mathrm{mM})$ with several UPOs $(2 \mu \mathrm{M})$ at pH 7.0 or 5.5 .

\begin{tabular}{ccccccc}
\hline \multirow{2}{*}{ Enzyme $(\boldsymbol{\mu M})$} & $\mathbf{p H}$ & Total $(\boldsymbol{\mu M})$ & \multicolumn{4}{c}{ Products $(\mathbf{\%})$} \\
\cline { 4 - 7 } & & & $\mathbf{E}$ & $\mathbf{3 - o l}$ & $\mathbf{H D}$ & $\mathbf{E D}$ \\
\hline \multirow{2}{*}{ AaeUPO } & 7.0 & 127 & 60 & 21 & 16 & 3 \\
& 5.5 & 110 & 61 & 21 & 18 & 0 \\
MroUPO & 7.0 & 89 & 95 & 5 & - & - \\
& 5.5 & 137 & 96 & 4 & - & - \\
rCciUPO & 7.0 & 265 & 43 & 19 & 26 & 12 \\
CglUPO & 5.5 & 317 & 44 & 18 & 27 & 11 \\
& 7.0 & 212 & 71 & 12 & 15 & 2 \\
rHinUPO & 5.5 & 164 & 70 & 11 & 14 & 5 \\
& 7.0 & 210 & 58 & 17 & 22 & 3 \\
rDcaUPO & 5.5 & 271 & 58 & 16 & 23 & 3 \\
& 7.0 & 160 & 44 & 22 & 28 & 4 \\
& 5.5 & 180 & 45 & 20 & 27 & 8 \\
\hline
\end{tabular}

The $\mathrm{pH}$ of the reaction mixture had a significant effect on substrate conversion and all enzymes attained a higher percentage conversion of 1-tetradecene at $\mathrm{pH} 5.5$ than at $\mathrm{pH} 7.0$, with the exception of $C g l \mathrm{UPO}$ and $A a e \mathrm{UPO}$. In agreement with these results, previous studies reported that a neutral $\mathrm{pH}$ was preferred for AaeUPO [28] and CglUPO [40] in diverse oxyfunctionalizations, while pH 5.5 was optimal for MroUPO [47]. However, the relative abundance of the differently oxygenated products was not affected by the $\mathrm{pH}$.

Among the UPOs tested, the most selective enzyme regarding epoxidation was MroUPO, producing 96\% of 1,2-epoxytetradecane and $4 \%$ of the alkene hydroxylated at the allylic position (tetradecen-3-ol, Table 2). The other UPOs were less selective, since, in addition to the epoxide, they generated tetradecen-3-ol together with other monohydroxylated alkene derivatives, substituted either at the subterminal positions $\omega-1$ and $\omega-2$ (AaeUPO, rCciUPO, and CglUPO) or at medium positions (between $\omega-3$ and $\omega-11$ ) in the case of $\mathrm{CglU}$ UPO, rHinUPO, and rDcaUPO. Previous studies using 1-tetradecene as the substrate resulted in only $1 \%$ conversion with $\mathrm{rCciUPO}$ and no reaction with AaeUPO, while over $80 \%$ and $10 \%$ conversion, respectively, were achieved using 7 -tetradecene as the substrate under otherwise identical conditions [32]. 


\subsection{Selective Epoxidation of Different Long-Chain Alkenes by UPOs}

Once the selectivity for 1-tetradecene epoxidation by the various UPOs was verified, a comparative study was performed with a series of long-chain terminal alkenes $\left(C_{12: 1}-C_{20: 1}\right)$ to determine whether the chain length of the substrates affected their conversion and reaction selectivity.

GC-MS analyses (as shown in Figure S3 for the 1-tetradecene reactions) revealed that all UPOs transformed the nine alkenes tested, although to different extents (Figure 2 and Table S1). GC-MS analyses of the corresponding controls, with $\mathrm{H}_{2} \mathrm{O}_{2}$ and without enzymes (as shown in Figure S4 for 1-tetradecene reactions), verified that no oxygenation was produced in the absence of enzymes. In general, rCciUPO (Figure 2C) was the most efficient enzyme, transforming up to $650 \mu \mathrm{M}$ of the substrate $\left(\mathrm{C}_{14: 1}\right)$, followed by CglUPO (Figure 2D), and then by rHinUPO (Figure 2E) and MroUPO (Figure 2B). AaeUPO (Figure 2A) and $\mathrm{rDcaUPO}$ (Figure 2F) were less efficient under the conditions used, only achieving $200 \mu \mathrm{M}$ products. The chain-length of alkenes had no notable influence on the conversion (at least below $\mathrm{C}_{17: 1}$ ), except in the case of $C_{g} I \mathrm{UPO}$ and $\mathrm{rDcaUPO}$. The alkenes with higher chain lengths $\left(C_{18: 1}-C_{20: 1}\right)$ were less converted, especially $C_{20: 1}$, with the noteworthy exception of MroUPO, which was the only enzyme clearly not affected by chain length.

Among the UPOs tested, the most selective enzyme toward the epoxidation of the different alkenes was MroUPO, producing $96 \%$ of 1,2-epoxytetradecane and only $4 \%$ of hydroxylated alkene derivatives, the main hydroxy-alkene being tetradecen-3-ol. The other UPOs were not as selective as MroUPO (with AaeUPO and rDcaUPO being less selective), because, in addition to the epoxide, they generated considerable amounts of other hydroxylated alkene derivatives (mainly at the allylic position, 3-ol). Furthermore, in some cases, the overoxygenation of these products led to the formation of dihydroxylated products and carboxylic acids, especially evident in the rCciUPO reactions (Figures 2 and S3). No ring opening was observed in any reaction.

Regarding the hydroxylated products obtained, the allylic position was favored in all cases, yielding the corresponding alken-3-ol (Figure S2A). AaeUPO and rCciUPO were also able to hydroxylate the subterminal positions, yielding the $\omega-1$ and $\omega-2$ hydroxylated alkene derivatives, as shown by mass spectra (Figure S2B,C, respectively). Interestingly, only the UPOs of ascomycetous species (namely CglUPO, rHinUPO, and rDcaUPO) were able to hydroxylate the molecule at different positions of the alkyl chain, resulting in a variety of hydroxylated alkenes (Figure 2D-F). Among the UPOs tested, MroUPO was the most regioselective enzyme, mainly yielding the epoxides as products (Figures 2B and S2), while rCciUPO was the least selective enzyme, always yielding mixtures of four or more products (Figures 2C and S2).

To the best of our knowledge, the epoxidation of long-chain terminal alkenes by enzymes is reported here for the first time. A previous study (only including AaeUPO) was carried out with short-chain terminal alkenes $\left(C_{3: 1}\right.$ to $\left.C_{8: 1}\right)$ but the product amounts were one to two orders lower (10 to $194 \mu \mathrm{M})$ [33]. Variants of P450 BM-3 were reported to epoxidize short terminal alkenes $\left(C_{5: 1}\right.$ to $\left.C_{8: 1}\right)$ but not alkenes with more carbon atoms [22]. Likewise, studies with methane monooxygenase showed that this enzyme is unable to oxygenate terminal alkenes with more than five carbon atoms [20]. 

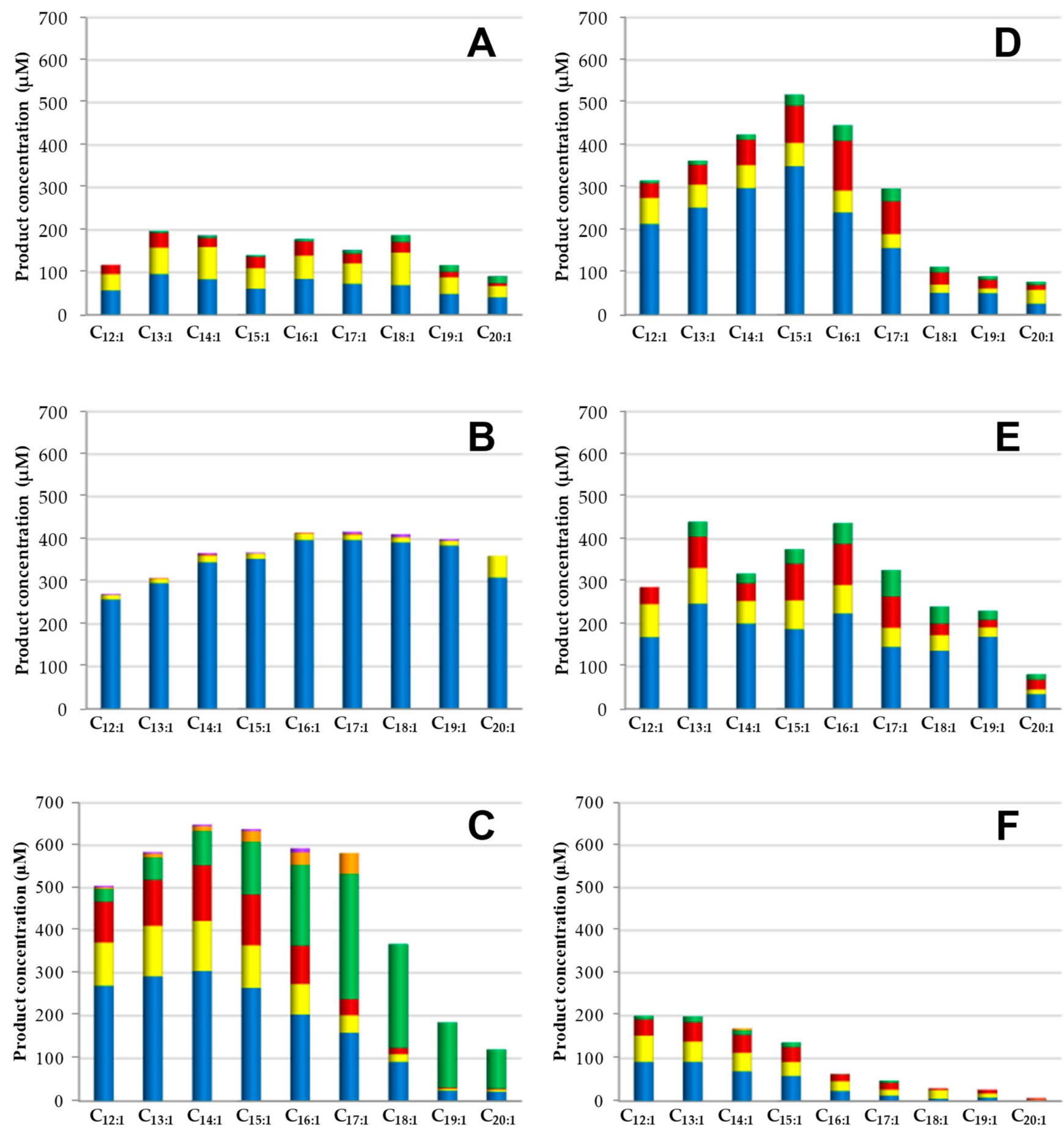

$\mathrm{E}$

3-ol

HD

ED

di-OH

$\mathrm{COOH}$

Figure 2. Enzymatic reactions of $1 \mathrm{mM}$ long-chain terminal alkenes $\left(C_{12: 1}\right.$ to $\left.C_{20: 1}\right)$ with $3 \mu M$ of UPOs. AaeUPO (A); MroUPO (B); rCciUPO (C); CglUPO (D); rHinUPO (E); rDcaUPO (F) within 2 h reaction and with $3 \mathrm{mM} \mathrm{H}_{2} \mathrm{O}_{2}$ (in 60\% acetone). Products: 1,2-epoxy-alkanes (E, blue), 3-hydroxy-alkenes (3-ol, yellow), monohydroxylated alkenes (HD, red), monohydroxylated epoxy-alkanes (ED, green), dihydroxy alkenes (di-OH, orange), and carboxylic acids ( $\mathrm{COOH}$, purple).

\section{Conclusions}

The enzymatic epoxidation of terminal alkenes by UPOs is limited, probably due to alkylation of the heme group (or of catalytically relevant amino acid residues) by the 
epoxidized products, causing inactivation of the enzyme. Despite this, the present results showed how several wild and recombinant UPOs are able to epoxidize long-chain alkenes (from $C_{12: 1}$ to $C_{20: 1}$ ) using $60 \%$ acetone as a cosolvent.

In these reactions, MroUPO appears to be the most selective UPO, being able to epoxidize the terminal double bond with the corresponding 1,2-epoxyalkane representing over $95 \%$ of the reaction products. $\mathrm{rCciUPO}$, although less specific, produced the highest amount and variety of products, such as epoxy-, hydroxy-, and hydroxy-epoxy derivatives; dihydroxy alkenes; and carboxylic acids.

Regarding alkene hydroxylation, the allylic position was preferred by all UPOs. Furthermore, the formation of hydroxylated derivatives at (sub)terminal positions was observed in the reactions with the basidiomycetous UPOs, while additional positions were hydroxylated by the UPOs from Ascomycota.

This work shows for the first time the ability of some UPOs to oxygenate long-chain $\left(\mathrm{C}_{12: 1}-\mathrm{C}_{20: 1}\right)$ terminal alkenes, yielding reactive epoxides that are of interest as building blocks in the pharmaceutical, flavoring, and polymer sectors.

Supplementary Materials: The following supporting information can be downloaded at: https:// www.mdpi.com/article/10.3390/antiox11030522/s1, Figure S1: Mass spectra of epoxy- and hydroxyepoxy- alkanes, the latter as trimethylsilyl derivatives, from reactions of 1-tetradecene with $\mathrm{rCciUPO}$. (A) 1,2-epoxytetradecane, (B) 1,2-epoxytetradec-13-ol; and (C) 1,2-epoxytetradec-12-ol; Figure S2: Mass spectra of hydroxy-alkenes, as trimethylsilyl derivatives, from reactions of 1-tetradecene with rCciUPO; (A) tetradecen-3-ol, (B) tetradecen-13-ol, and (C) tetradecen-12-ol; Figure S3: GC-MS analysis of 1-tetradecene (1 mM) reactions (2 h) with $3 \mu \mathrm{M}$ Aae UPO (A), MroUPO (B), rCciUPO (C), CglUPO (D), rHinUPO (E) and rDcaUPO (F). The main products are 1,2-epoxytetradecane (E) and several monohydroxy alkenes (1-ol, 3-ol, 12-ol and 13-ol), together with some epoxy derivatives (ED) and dihydroxy (di-OH) and carboxylic $(\mathrm{COOH})$ alkene derivatives. The chromatograms are normalized to same total-ion vertical scale for comparison; Figure S4: GC-MS analysis of 1-tetradecene $(1 \mathrm{mM})$ reactions $\left(2 \mathrm{~h}\right.$ ) including control reaction with $3 \mathrm{mM} \mathrm{H}_{2} \mathrm{O}_{2}$ and without enzyme (A), enzymatic reaction with $3 \mu \mathrm{M}$ MroUPO and $3 \mathrm{mM} \mathrm{H}_{2} \mathrm{O}_{2}$ (B) and enzymatic reaction with $3 \mu \mathrm{M} \mathrm{rCciUPO}$ and $3 \mathrm{mM} \mathrm{H}_{2} \mathrm{O}_{2}$ (C); Table S1: Inventory of products in the reactions $(2 \mathrm{~h}, 60 \%$ acetone, and $3 \mathrm{mM}$ $\mathrm{H}_{2} \mathrm{O}_{2}$ ) of nine terminal alkenes ( $\left.1 \mathrm{mM} \mathrm{C}_{12: 1}-\mathrm{C}_{20: 1}\right)$ with six UPOs $(3 \mu \mathrm{M})$ yielding: 1,2-epoxy- $(\mathrm{E})$, 3-hydroxy-(3-ol), other hydroxy- (HD), hydroxy-epoxy- (ED), dihydroxy- (di-OH), and carboxylic$(\mathrm{COOH})$ derivatives.

Author Contributions: Conceptualization, C.A. and A.G.; methodology, E.D.B. and C.A.; formal analysis, E.D.B., C.A. and A.G.; investigation, E.D.B. and C.A.; resources, J.K., K.S., R.U. and M.H.; data curation, E.D.B. and C.A.; writing-original draft preparation, E.D.B. and C.A.; writing-review and editing, A.G. and A.T.M.; visualization, C.A.; supervision, A.G.; project administration, A.G.; funding acquisition, A.G. and A.T.M. All authors have read and agreed to the published version of the manuscript.

Funding: This research was funded by BioBased Industries Joint Undertaking under the European Union's Horizon 2020 Research and Innovation Programme, grant number 792063 (SusBind project; https: / / susbind.eu, accessed on 1 February 2022; to A.G., A.T.M. and M.H.); the PID2020118968RB-100 project of the Spanish MCIN/AEI/10.13039/501100011033 to A.G.; the CSIC projects PIE-202040E185 (to A.G.) and PIE-202120E019 (to A.T.M.); the CSIC SusPlast platform (to A.T.M.); and the CSIC program for the Spanish Recovery, Transformation and Resilience Plan funded by the Recovery and Resilience Facility of the European Union, established by the Regulation (EU) $2020 / 2094$.

Informed Consent Statement: Not applicable.

Data Availability Statement: Data are contained within the article.

Acknowledgments: We thank Novozymes A/S for kindly providing rCciUPO, rHinUPO, and rDcaUPO.

Conflicts of Interest: The authors declare no conflict of interest. 


\section{References}

1. Maisonneuve, L.; Lamarzelle, O.; Rix, E.; Grau, E.; Cramail, H. Isocyanate-free routes to polyurethanes and poly(hydroxy urethane)s. Chem. Rev. 2015, 115, 12407-12439. [CrossRef] [PubMed]

2. Pérez-Sena, W.Y.; Cai, X.; Kebir, N.; Vernières-Hassimi, L.; Serra, C.; Salmi, T.; Leveneur, S. Aminolysis of cyclic-carbonate vegetable oils as a non-isocyanate route for the synthesis of polyurethane: A kinetic and thermal study. Chem. Eng. J. 2018, 346, 271-280. [CrossRef]

3. Maisonneuve, L.; Wirotius, A.L.; Alfos, C.; Grau, E.; Cramail, H. Fatty acid-based (bis) 6-membered cyclic carbonates as efficient isocyanate free poly(hydroxyurethane) precursors. Polym. Chem. 2014, 5, 6142-6147. [CrossRef]

4. Coombs, J.R.; Morken, J.P. Catalytic enantioselective functionalization of unactivated terminal alkenes. Angew. Chem. Int. Ed. 2016, 55, 2636-2649. [CrossRef] [PubMed]

5. Palumbo, C.; Tiozzo, C.; Ravasio, N.; Psaro, R.; Carniato, F.; Bisio, C.; Guidotti, M. An efficient epoxidation of terminal aliphatic alkenes over heterogeneous catalysts: When solvent matters. Catal. Sci. Technol. 2016, 6, 3832-3839. [CrossRef]

6. Köckritz, A.; Martin, A. Oxidation of unsaturated fatty acid derivatives and vegetable oils. Eur. J. Lipid Sci. Technol. 2008, 110, 812-824. [CrossRef]

7. Wentzel, B.B.; Alsters, P.L.; Feiters, M.C.; Nolte, R.J.M. Mechanistic studies on the Mukaiyama epoxidation. J. Org. Chem. 2004, 69, 3453-3464. [CrossRef]

8. Aguirre, P.; Zolezzi, S.; Parada, J.; Bunel, E.; Moya, S.A.; Sariego, R. Ruthenium carbonyl complexes in catalytic epoxidation of olefins co-catalyzed by isobutyl-aldehyde. Appl. Organometal. Chem. 2006, 20, 260-263. [CrossRef]

9. Abraham, M.E.; Benenati, R.F. Kinetics and mechanism of the epoxidation of unsaturated fatty acids. AIChE J. 1972, 18, 807-811. [CrossRef]

10. Cai, X.; Zheng, J.L.; Aguilera, A.F.; Vernières-Hassimi, L.; Tolvanen, P.; Salmi, T.; Leveneur, S. Influence of ring-opening reactions on the kinetics of cottonseed oil epoxidation. Int. J. Chem. Kinet. 2018, 50, 726-741. [CrossRef]

11. Pérez-Sena, W.Y.; Wärnå, J.; Eränen, K.; Tolvanen, P.; Estel, L.; Leveneur, S.; Salmi, T. Use of semibatch reactor technology for the investigation of reaction mechanism and kinetics: Heterogeneously catalyzed epoxidation of fatty acid esters. Chem. Eng. Sci. 2021, 230, 116206. [CrossRef]

12. Zheng, J.L.; Wärnå, J.; Salmi, T.; Burel, F.; Taouk, B.; Leveneur, S. Kinetic modeling strategy for an exothermic multiphase reactor system: Application to vegetable oils epoxidation using Prileschajew method. AIChE J. 2016, 62, 726-741. [CrossRef]

13. Sato, K.; Aoki, M.; Ogawa, M.; Hashimoto, T.; Noyori, R. A practical method for epoxidation of terminal olefins with $30 \%$ hydrogen peroxide under halide-free conditions. J. Org. Chem. 1996, 61, 8310-8311. [CrossRef] [PubMed]

14. Shen, Y.; Jiang, P.; Wai, P.T.; Gu, Q.; Zhang, W. Recent progress in application of molybdenum-based catalysts for epoxidation of alkenes. Catalysts 2019, 9, 31. [CrossRef]

15. Grigoropoulou, G.; Clark, J.H.; Elings, J.A. Recent developments on the epoxidation of alkenes using hydrogen peroxide as an oxidant. Green Chem. 2003, 5, 1-7. [CrossRef]

16. Peckh, K.; Lisicki, D.; Talik, G.; Orlinska, B. Oxidation of long-chain a-olefins using environmentally-friendly oxidants. Materials 2020, 13, 4545. [CrossRef]

17. Xu, Y.; Khaw, N.R.B.J.; Li, Z. Efficient epoxidation of alkenes with hydrogen peroxide, lactone, and lipase. Green Chem. 2009, 11, 2047-2051. [CrossRef]

18. McClay, K.; Fox, B.G.; Steffan, R.J. Toluene monooxygenase-catalyzed epoxidation of alkenes. Appl. Environ. Microbiol. 2000, 66, 1877-1882. [CrossRef] [PubMed]

19. Schmid, A.; Hofstetter, K.; Feiten, H.J.; Hollmann, F.; Witholt, B. Integrated biocatalytic synthesis on gram scale: The highly enantioselective preparation of chiral oxiranes with styrene monooxygenase. Adv. Synth. Catal. 2001, 343, 732-737. [CrossRef]

20. Elliott, S.J.; Zhu, M.; Tso, L.; Nguyen, H.H.; Yip, J.H.K.; Chan, S.I. Regio- and stereoselectivity of particulate methane monooxygenase from Methylococcus capsulatus (Bath). J. Am. Chem. Soc. 1997, 119, 9949-9955. [CrossRef]

21. Geigert, J.; Lee, T.D.; Dalietos, D.J.; Hirano, D.S.; Neidleman, S.L. Epoxidation of alkenes by chloroperoxidase catalysis. Biochem. Biophys. Res. Commun. 1986, 136, 778-782. [CrossRef]

22. Kubo, T.; Peters, M.W.; Meinhold, P.; Arnold, F.H. Enantioselective epoxidation of terminal alkenes to $(R)$ - and $(S)$-epoxides by engineered cytochromes P450 BM-3. Chem. Eur. J. 2006, 12, 1216-1220. [CrossRef] [PubMed]

23. Toda, H.; Ohuchi, T.; Imae, R.; Itoh, N. Microbial production of aliphatic (S)-epoxyalkanes by using Rhodococcus sp. strain ST-10 styrene monooxygenase expressed in organic-solvent-tolerant Kocuria rhizophila DC2201. Appl. Environ. Microbiol. 2015, 81, 1919. [CrossRef] [PubMed]

24. Hofrichter, M.; Kellner, H.; Herzog, R.; Karich, A.; Kiebist, J.; Scheibner, K.; Ullrich, R. Peroxide-mediated oxygenation of organic compounds by fungal peroxygenases. Antioxidants 2022, 11, 163. [CrossRef]

25. Carro, J.; González-Benjumea, A.; Fernández-Fueyo, E.; Aranda, C.; Guallar, V.; Gutiérrez, A.; Martínez, A.T. Modulating fatty acid epoxidation vs hydroxylation in a fungal peroxygenase. ACS Catal. 2019, 9, 6234-6242. [CrossRef]

26. Municoy, M.; González-Benjumea, A.; Carro, J.; Aranda, C.; Linde, D.; Renau-Mínguez, C.; Ullrich, R.; Hofrichter, M.; Guallar, V.; Gutiérrez, A.; et al. Fatty-acid oxygenation by fungal peroxygenases: From computational simulations to preparative regio- and stereo-selective epoxidation. ACS Catal. 2020, 10, 13584-13595. [CrossRef]

27. Aranda, C.; Carro, J.; González-Benjumea, A.; Babot, E.D.; Olmedo, A.; Linde, D.; Martínez, A.T.; Gutiérrez, A. Advances in enzymatic oxyfunctionalization of aliphatic compounds. Biotechnol. Adv. 2021, 51, 107703. [CrossRef] 
28. Hofrichter, M.; Ullrich, R.; Pecyna, M.J.; Liers, C.; Lundell, T. New and classic families of secreted fungal heme peroxidases. Appl. Microbiol. Biotechnol. 2010, 87, 871-897. [CrossRef] [PubMed]

29. Aranda, C.; Ullrich, R.; Kiebist, J.; Scheibner, K.; del Río, J.C.; Hofrichter, M.; Martínez, A.T.; Gutiérrez, A. Selective synthesis of the resveratrol analogue 4,4'-dihydroxy-trans-stilbene and stilbenoids modification by fungal peroxygenases. Catal. Sci. Technol. 2018, 8, 2394-2401. [CrossRef]

30. Gutiérrez, A.; Babot, E.D.; Ullrich, R.; Hofrichter, M.; Martínez, A.T.; del Río, J.C. Regioselective oxygenation of fatty acids, fatty alcohols and other aliphatic compounds by a basidiomycete heme-thiolate peroxidase. Arch. Biochem. Biophys. 2011, 514, 33-43. [CrossRef]

31. Peter, S.; Kinne, M.; Wang, X.; Ulrich, R.; Kayser, G.; Groves, J.T.; Hofrichter, M. Selective hydroxylation of alkanes by an extracellular fungal peroxygenase. FEBS J. 2011, 278, 3667-3675. [CrossRef]

32. Babot, E.D.; del Río, J.C.; Kalum, L.; Martínez, A.T.; Gutiérrez, A. Oxyfunctionalization of aliphatic compounds by a recombinant peroxygenase from Coprinopsis cinerea. Biotechnol. Bioeng. 2013, 110, 2332. [CrossRef] [PubMed]

33. Peter, S.; Kinne, M.; Ullrich, R.; Kayser, G.; Hofrichter, M. Epoxidation of linear, branched and cyclic alkenes catalyzed by unspecific peroxygenase. Enzym. Microb. Technol. 2013, 52, 370-376. [CrossRef] [PubMed]

34. Olmedo, A.; Aranda, C.; del Río, J.C.; Kiebist, J.; Scheibner, K.; Martínez, A.T.; Gutiérrez, A. From alkanes to carboxylic acids: Terminal oxygenation by a fungal peroxygenase. Angew. Chem. Int. Ed. 2016, 55, 12248-12251. [CrossRef]

35. Aranda, C.; Olmedo, A.; Kiebist, J.; Scheibner, K.; del Río, J.C.; Martínez, A.T.; Gutiérrez, A. Selective epoxidation of fatty acids and fatty acid methyl esters by fungal peroxygenases. ChemCatChem 2018, 10, 3964-3968. [CrossRef]

36. González-Benjumea, A.; Carro, J.; Renau, C.; Linde, D.; Fernández-Fueyo, E.; Gutiérrez, A.; Martínez, A.T. Fatty acid epoxidation by Collariella virescens peroxygenase and heme-channel variants. Catal. Sci. Technol. 2020, 10, 717-725. [CrossRef]

37. Linde, D.; Olmedo, A.; González-Benjumea, A.; Renau, C.; Estévez, M.; Carro, J.; Fernández-Fueyo, E.; Gutiérrez, A.; Martínez, A.T. Two new unspecific peroxygenases from heterologous expression of fungal genes in Escherichia coli. Appl. Environ. Microbiol. 2020, 86, e02899-19. [CrossRef]

38. Olmedo, A.; del Río, J.C.; Kiebist, J.; Scheibner, K.; Martínez, A.T.; Gutiérrez, A. Fatty acid chain shortening by a fungal peroxygenase. Chem. Eur. J. 2017, 23, 16985-16989. [CrossRef]

39. Babot, E.D.; del Río, J.C.; Cañellas, M.; Sancho, F.; Lucas, F.; Guallar, V.; Kalum, L.; Lund, H.; Gröbe, G.; Scheibner, K.; et al. Steroid hydroxylation by basidiomycete peroxygenases: A combined experimental and computational study. Appl. Environ. Microbiol. 2015, 81, 4130-4142. [CrossRef]

40. Kiebist, J.; Schmidtke, K.U.; Zimmermann, J.; Kellner, H.; Jehmlich, N.; Ullrich, R.; Zänder, D.; Hofrichter, M.; Scheibner, K. A peroxygenase from Chaetomium globosum catalyzes the selective oxygenation of testosterone. ChemBioChem 2017, 18, 563-569. [CrossRef]

41. Babot, E.D.; del Río, J.C.; Kalum, L.; Martínez, A.T.; Gutiérrez, A. Regioselective hydroxylation in the production of 25hydroxyvitamin D by Coprinopsis cinerea peroxygenase. ChemCatChem 2015, 7, 283-290. [CrossRef]

42. Lucas, F.; Babot, E.D.; del Río, J.C.; Kalum, L.; Ullrich, R.; Hofrichter, M.; Guallar, V.; Martínez, A.T.; Gutiérrez, A. Molecular determinants for selective C25-hydroxylation of vitamins D2 and D3 by fungal peroxygenases. Catal. Sci. Technol. 2016, 6, 288-295. [CrossRef]

43. Aranda, C.; Municoy, M.; Guallar, V.; Kiebist, J.; Scheibner, K.; Ullrich, R.; del Río, J.C.; Hofrichter, M.; Martínez, A.T.; Gutiérrez, A. Selective synthesis of 4-hydroxyisophorone and 4-ketoisophorone by fungal peroxygenases. Catal. Sci. Technol. 2019, 9, 1398-1405. [CrossRef]

44. Babot, E.D.; Aranda, C.; del Río, J.C.; Ullrich, R.; Kiebist, J.; Scheibner, K.; Hofrichter, M.; Martínez, A.T.; Gutiérrez, A. Selective oxygenation of ionones and damascones by fungal peroxygenases. J. Agric. Food Chem. 2020, 68, 5375-5383. [CrossRef]

45. Ullrich, R.; Nuske, J.; Scheibner, K.; Spantzel, J.; Hofrichter, M. Novel haloperoxidase from the agaric basidiomycete Agrocybe aegerita oxidizes aryl alcohols and aldehydes. Appl. Environ. Microbiol. 2004, 70, 4575-4581. [CrossRef]

46. Anh, D.H.; Ullrich, R.; Benndorf, D.; Svatos, A.; Muck, A.; Hofrichter, M. The coprophilous mushroom Coprinus radians secretes a haloperoxidase that catalyzes aromatic peroxygenation. Appl. Environ. Microbiol. 2007, 73, 5477-5485. [CrossRef] [PubMed]

47. Gröbe, G.; Ullrich, M.; Pecyna, M.; Kapturska, D.; Friedrich, S.; Hofrichter, M.; Scheibner, K. High-yield production of aromatic peroxygenase by the agaric fungus Marasmius rotula. AMB Express 2011, 1, 31-42. [CrossRef]

48. Landvick, S.; Ostergaard, L.H.; Kalum, L. Polypeptides Having Peroxygenase Activity. International Patent WO2014056916A3, 17 April 2014

49. Collman, J.P.; Hampton, P.D.; Brauman, J.T. Suicide inactivation of cytochrome P-450 model compounds by terminal olefins. 1. A mechanistic study of heme $\mathrm{N}$-alkylation and epoxidation. J. Am. Chem. Soc. 1990, 112, 2977-2986. [CrossRef]

50. Lund, H.; Kalum, L.; Hofrichter, M.; Peter, S. Epoxidation Using Peroxygenase. U.S. Patent US9908860B2, 6 March 2018.

51. González-Benjumea, A.; Marques, G.; Herold-Majumdar, O.M.; Kiebist, J.; Scheibner, K.; del Río, J.C.; Martínez, A.T.; Gutiérrez, A. High epoxidation yields of vegetable oil hydrolyzates and methyl esters by selected fungal peroxygenases. Front. Bioeng. Biotechnol. 2021, 8, 605854. [CrossRef] [PubMed]

52. Pecyna, M.J.; Schnorr, K.M.; Ullrich, R.; Scheibner, K.; Kluge, M.G.; Hofrichter, M. Fungal Peroxygenases and Methods of Application. International Patent WO2008/119780A2, 9 October 2008.

53. Otey, C.R. High-throughput carbon monoxide binding assay for cytochromes P450. Methods Mol. Biol. 2003, 230, 137-139. 
54. Meng, Y.; Taddeo, F.; Aguilera, A.F.; Cai, X.; Russo, V.; Tolvanen, P.; Leveneur, S. The Lord of the chemical rings: Catalytic synthesis of important industrial epoxide compounds. Catalysts 2021, 11, 765. [CrossRef]

55. Karich, A.; Scheibner, K.; Ullrich, R.; Hofrichter, M. Exploring the catalase activity of unspecific peroxygenases and the mechanism of peroxide-dependent heme destruction. J. Mol. Catal. B Enzym. 2016, 134, 238-246. [CrossRef] 